\title{
The drug addicted patient
}

$\mathrm{T}$ HE use of illicit drugs in Canada is not well documented. It is estimated that as many as one in five adult Canadians, or $4,200,000$ people have used an illegal substance at least once over their lifetime. The most widely used illicit drug is cannabis (marijuana or hashish), used by $20 \%$ of adult Canadians over their lifetime. Three percent or 640,000 people say they have used cocaine, crack, or LSD. Two percent or 427,000 people have used amphetamines (speed), and $<1 \%$ or 213,000 people have used heroin in their lifetime. Over the past five years, the annual use of all drugs by Canadians declined, especially that of cannabis and cocaine. Overall, illicit drug use is highest among those with the lowest income levels, who are outside the work force living in larger urban centres. ${ }^{1}$ A recent study demonstrated that $57 \%$ of the violent assault victims and $22 \%$ of automobile trauma victims presenting to a US trauma centre had urine or blood tests positive for cocaine and/or its metabolites. ${ }^{2}$

Still, the use of illicit drugs presents one of the most difficult challenges to the anaesthetist. This is particularly true of patients presenting for emergency surgery. For example, a young man who sustained an open compound lower extremity fracture during a motor vehicle accident secondary to cocaine intoxication, presented with tachyarrhythmia, myocardial ischaemic changes, and metabolic acidosis. Or, a parturient admitted at 30-wk gestation in preterm labour with fetal bradycardia, haemorrhage due to abruptio placenta, hypertension, and cardiac arrhythmias secondary to recent cocaine use, for an emergency caesarean section. In the drug addicted patient, polydrug abuse is the rule rather than the exception.

This lecture serves to heighten awareness about this important problem and to examine the perioperative anaesthetic management of these patients, particularly for cocaine abuse. 3,4

\section{Preoperative assessment}

A high index of suspicion is required as patients often do not volunteer drug addiction information. The diagnosis should be considered in patients with pupillary constriction, trackmarks, thrombotic veins, localized oedema over veins, subcutaneous abscesses or scarring, tattoos, lymphadenopathy, hepatomegaly, bizarre behaviour, or a history of drug-associated diseases. If the diagnosis is suspected, a urinary drug screen should be obtained. The presenting symptoms are mostly cardiopulmonary, psychiatric and neurological. Table I outlines the common signs and symptoms of substance abuse.

Drug abuse in pregnancy involves a wide range of substances and clinical presentations. There is a strong

TABLE I Signs and symptoms of substance abuse

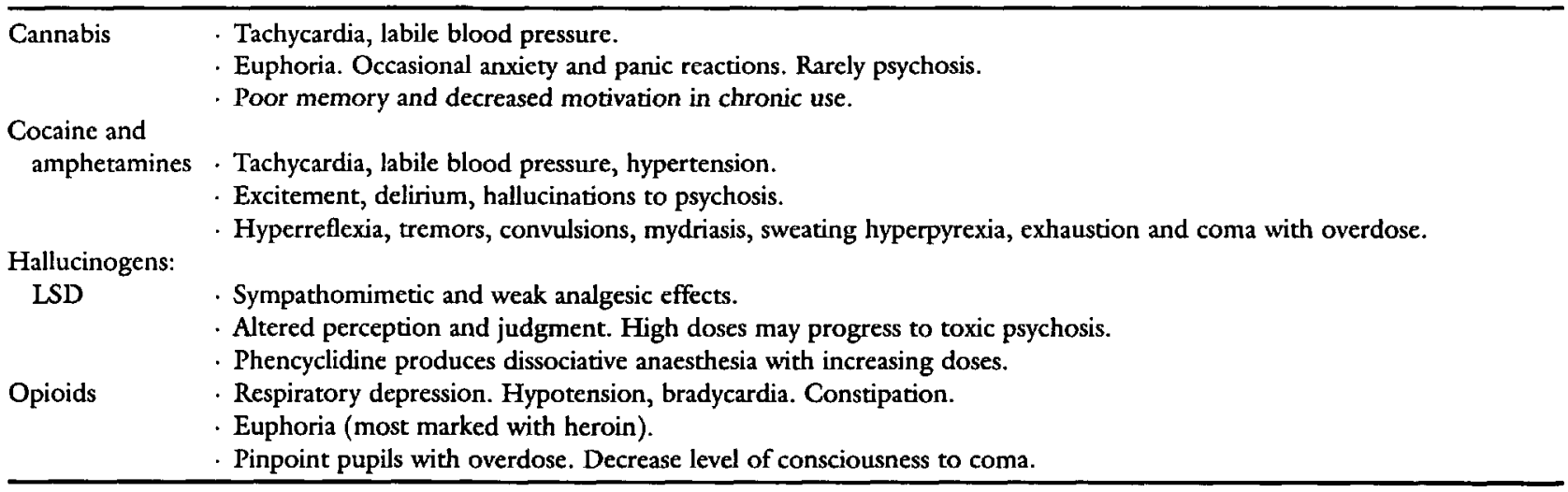

From the Department of Anaesthesia, Toronto Hospital, General Division, 200 Elizabeth Street, Toronto, Ontario M5G 2 C4. 
association between lack of prenatal care and drug abuse. ${ }^{5} \mathrm{Up}$ to $50 \%$ of women who abuse illicit drugs in pregnancy have at least one significant medical or surgical complication. These include anaemia (especially due to folate deficiency), acute and chronic hepatitis, sexually transmitted disease, septicaemia, bacterial endocarditis, thrombophlebitis, pneumonia, urinary tract infection, AIDS, psychiatric illness, and severe malnutrition. The major obstetric complications are intra-uterine growth retardation, premature labour, hypertension, breech presentation, and antepartum haemorrhage. ${ }^{6}$

\section{Cocaine}

Those who abuse cocaine because of its stimulating effects frequently do so by sniffing its fine white powder, often called "snow." In the mid-1980s, however, the use of "crack," a new, relatively inexpensive form of cocaine, surged. Crack is highly concentrated, chemically reconstituted cocaine, in a pebble-like shape, that users smoke. By 1990 , the use of highly addictive crack became the most widely abused illicit drug in the United States.

Topical intranasal cocaine $\left(1.5 \mathrm{mg} \cdot \mathrm{kg}^{-1}\right)$ is rapidly absorbed with peak plasma concentrations (120-474 $\mathrm{ng} \cdot \mathrm{ml}^{-1}$ ) occurring within $30-60 \mathrm{~min}$ and is still detectable in plasma for up to six hours. ${ }^{7}$ Cocaine has a biological half-life of $0.5-1.5 \mathrm{hr}$, a volume of distribution of $2 \mathrm{~L} \cdot \mathrm{kg}^{-1}$, and a systemic clearance of 2 $\mathrm{L} \cdot \mathrm{min}^{-1}$. Only $\mathrm{l}-5 \%$ of cocaine is cleared unmetabolized in urine where it may be detected for three to six hours after use. However, its two major metabolites $(80 \%)$, ecgonine methyl ester and benzoylecgonine, can be detected in urine for 14-60 hr after cocaine administration. Metabolically, cocaine is hydrolyzed by plasma cholinesterase. ${ }^{8}$

The presenting symptoms of cocaine toxicity are mainly cardiopulmonary (40\%), psychiatric $(22 \%)$, and neurological $(13 \%)$. It is important to remember that these patients usually abuse multiple drugs. Cocaine produces central and peripheral adrenergic stimulation by:

Inhibiting the presynaptic re-uptake of dopamine ${ }^{9}$

Increasing dopamine release ${ }^{10}$

Increasing levels of adenyl cyclase and cAMPdependent protein kinase (PKA) $)^{11}$

Cardiopulmonary: Examination may reveal tachycardia, severe hypertension, acute aortic dissection, cardiac arrhythmia, ventricular fibrillation, myocardial ischaemia, infarction, and sudden death. ${ }^{4}$ Cocaine can cause accelerated coronary artery disease, induce coronary spasm, and reduce coronary blood flow. ${ }^{12}$ Alveolar haemorrhage or pulmonary oedema can also result from cocaine inhalation. ${ }^{13,14}$
Psychiatric: These patients may manifest feelings of excitation, elation, well-being, enhanced physical strength and mental capacity, and a lessened sense of fatigue. The chronic user can develop a full toxic paranoid psychosis which can lead to violent antisocial behavior. Long-term use can also result in weight loss, deterioration of the nervous system, and digestive problems. Cocaine is psychologically habit-forming. Abrupt withdrawal is followed by hunger, fatigue, and depression. ${ }^{15}$

Neurological: Patients may present with cerebral vasospasm, ischaemia or stroke, seizure, hyperpyrexia, and muscle rigidity. ${ }^{19}$ During general anaesthesia, hyperpyrexia (to $41^{\circ} \mathrm{C}$ ) and sympathomimetic activity of a cocaine overdose can mimic malignant hyperthermia. ${ }^{16}$

Renal: The most commonly reported renal complication has been myoglobinuric renal failure secondary to rhabdomyolysis. ${ }^{17}$ There have been cases reported of renal infarction secondary to intravenous cocaine abuse, ${ }^{18}$ and secondary to nasal insufflation of cocaine. ${ }^{19}$

Endocrine: There is a considerably increased secretion of adrenocorticotropic hormone (ACTH) after acute cocaine administration. It is postulated that cocaine stimulates the release of corticotropin releasing factor and that the cocaine-induced secretion of corticotropin releasing factor increases the amplitude of ACTH pulses, because ACTH pulse frequency is not altered by cocaine. ${ }^{20}$ The relationship between increased ACTH secretion and its associated complications of hypertension and psychiatric disturbances in cocaine abusers needs further investigation.

\section{Intraoperative management and drug interactions}

The acute fatal cocaine toxicity of cardiac arrhythmia, pulmonary oedema, coronary spasm, myocardial ischaemia, and sudden death may never reach our operating rooms. It is the sublethal cocaine toxicity cases that we are concerned with and drug interactions are the prominent causes of perioperative morbidity and mortality. During adverse reaction, the primary efforts should be directed toward airway protection, maintenance of adequate ventilation, control of cardiac rhythm and haemodynamics, suppression of seizures, and temperature regulation. ${ }^{3}$

An interesting case report provides an unique opportunity to observe anaesthetic physiology and pharmacology during acute cocaine intoxication. ${ }^{21} \mathrm{~A}$ young woman sustained an open talus fracture during a motor vehicle accident. In fear of losing or being stolen, she had placed six "crack rocks" in her nose and under her tongue when she was called to the operating room. Neurologically, she required a much larger benzodiazepine dose to counteract the cocaine- 
mediated CNS stimulation and agitation. Acute cocaine intoxication decreased the effective potency of midazolam, because benzodiazepines act by increasing inhibitory GABAergic activity in the CNS. Another feature was the haemodynamic instability that ensued after the onset of agitation and subsequent induction of general anaesthesia.

\section{Local or regional anaesthesia}

The more needles in use the greater the risk to medical staff of transmissible hazards from needle stick injuries. Sepsis, coagulation disorder due to hepatic dysfunction, or existing peripheral neuropathy from drug addiction must be ruled out. Otherwise, there is no absolute contraindication to regional anaesthesia. Addition of adrenaline to local anaesthetic agents can induce tachycardia. In managing a case of acute upper limb ischaemia due to inadvertent intraarterial injection of cocaine, an axillary brachial-plexus block was performed with $40 \mathrm{ml}$ lidocaine $1 \%$ and was maintained for $36 \mathrm{hr}$ with a continuous flow of bupivacaine $0.5 \%$ through a catheter left in contact with the brachial plexus. For $48 \mathrm{hr}$ the patient was treated with a continuous iv infusion of heparin. This was followed by administration of aspirin and dipyridamole for six days. The clinical outcome was favourable. ${ }^{22}$ Several other approaches to the treatment of such toxic intraarterial injections have been suggested, including stellate ganglion block, administration of intraarterial vasodilators, systemic vasodilators, lowmolecular-weight dextran, or intraarterial urokinase, and early fasciotomy.

\section{General anaesthesia}

The precipitous systemic toxicity of cocaine and general anaesthesia is mostly reported anecdotally. It is rarely simple cause and effect, but usually involves an interaction of potent vasoactive drugs with cocaine. Cocaine markedly potentiates both direct-acting sympathomimetics and other vasoactive substrates for neuronal amine re-uptake. Topically, $1.5 \mathrm{mg} \cdot \mathrm{kg}^{-1}$ cocaine or plasma concentrations of $330 \mathrm{ng} \cdot \mathrm{ml}^{-1}$ do not exert any clinically significant sympathomimetic effects in anaesthetized patients with coronary artery disease. ${ }^{23}$ The overwhelming sympathetic stimulation from cocaine overdose can be suppressed by a deep plane of general anaesthesia. ${ }^{24}$ It appears that the influence of stimuli increasing endogenous circulating epinephrine and norepinephrine concentrations are more prone to cocaine-induced complications. Therefore, it is the interaction of vasoactive drugs with cocaine that warrants caution during general anaesthesia.

Halothane may potentially lower the minimal dysrhythmic dose of epinephrine. Ketamine also markedly potentiates the cardiovascular toxicity of cocaine..$^{25}$ Crack cocaine use and ketamine may predispose to the development of pulmonary artery hypertension and pulmonary oedema. ${ }^{26}$ An apparent transmural redistribution of blood flow unaffected by anaesthetic depth was observed during cocaine administration; possibly related to an interaction between demand-mediated increases in global myocardial perfusion and cocaineinduced epicardial coronary vasoconstriction. Blood flow to other major organs was preserved during isoflurane anaesthesia and cocaine toxicity, with the exception of reduced splenic blood flow. ${ }^{24}$ The cardiovascular and neurological toxicity of cocaine may relate to its high affinity and accumulation in these vessel-rich organs. Therefore, a sufficient depth of anaesthesia is important to control the cardiovascular effects of cocaine.

\section{Cardiovascular drugs}

Combined alpha and beta adrenergic blockade reduces the haemodynamic effects of cocaine more than beta blockade alone. ${ }^{27}$ Thus, propranolol is relatively contraindicated in the cocaine abusing patient, since beta blockade may cause unopposed alpha adrenergic stimulation and, therefore, worsen the hypertension. Labetalol offers better hypertension control with $\alpha$ - and B-blockade. ${ }^{28}$ Esmolol has allowed titratable control of hypertension without the $\alpha$-mediated coronary and peripheral vasoconstriction. ${ }^{29}$ Experimental studies have suggested that calcium channel blockers may be useful for cocaine cardiotoxicity..$^{30}$ In a pharmacological sense, the sodium channel blocking actions of cocaine per se do not lead to arrhythmic death. Other factors, such as sympathetic tone, may potentiate the arrhythmogenic effects of cocaine. Cocaine use in the chronic abuser may lead to left ventricular dysfunction, provoke ischaemia (vasospasm or accelerated coronary artery disease), and is a potent indirect sympathomimetic. When a combination of these factors co-exist with potent sodium blockade, cocaine could precipitate unexpected death due to ventricular arrhythmia. Cocaine and its metabolites depressed the sinus node rate. Hence, in the management of cocaine intoxication, drugs that inhibit plasma cholinesterase should probably be avoided. ${ }^{31}$

TABLE II Drugs Therapy for Cocainc Intoxication

\begin{tabular}{ll}
\hline Symptom & Therapy \\
\hline Hypertension/Tachycardia & Labetalol, esmolol \\
Arrhythmias & Lidocaine \\
Myocardial ischaemia & Nitroglycerin \\
Tremors /Convulsions & Benzodiazepines \\
\hline
\end{tabular}




\section{Vasoconstrictors}

There are a number of adverse reports in the surgical and anaesthesia literature regarding the interaction of cocaine and vasoconstrictors. Vasoconstrictors such as phenylephrine hydrochloride (neo-synephrine) ) $^{32,33}$ and felypressin ${ }^{34}$ can precipitate hypertensive crises, ventricular tachycardia, myocardial ischaemia, and myocardial infarction during acute cocaine toxicity.

\section{Psychiatric drugs}

Interaction with psychotropic drugs is unpredictable. Tricyclic antidepressants which block monoamine reuptake, e.g., amitriptyline, have been shown to have a protective effect on mortality only when administered either 10 days or one day before a lethal dose of cocaine was given to experimental animals. ${ }^{35}$ Phenelzine (monoamine oxidase inhibitor) has been implicated in causing delayed excitatory reaction of convulsion and hyperpyrexia. ${ }^{36}$ Benzodiazepines, which have an effect on the limbic system, appear to be the most appropriate therapy for cocaine-induced convulsions. Chlorpromazine has been used to treat hyperthermia, but may lower seizure threshold. ${ }^{37}$

\section{Postoperative management}

Postoperative ECG and arterial pressure monitoring are essential. Requirement for invasive cardiovascular monitoring depends on the perioperative course of the patients. Withdrawal from the stimulants cocaine and amphetamine can be difficult to recognize. Some abusers enter a prolonged sleep phase ("crash") (up to 24-48 hr) at the end of a period of chronic heavy usage followed by hunger, depression, delirium, delusions, and hallucinations. This is thought to represent catecholamine depletion, ${ }^{47}$ the opposite mechanism to that of acute intoxication. The syndrome should be left to run its course, but severe depression may warrant expert psychiatric help.

\section{Antenatal course and complications}

Perinatal cocaine abuse has been linked to numerous maternal-fetal complications including increased incidences of abruption, preterm labour, fetal distress requiring caesarean section, low birth weight infants, and congenital malformations. ${ }^{38}$ Cocaine abuse is associated with genitourinary tract abnormalities and vasoconstriction with impaired placental function or placental abruption ${ }^{39}$ leading to gut atresias, loss of digits, and cerebral infarction in utero. The cocaineabusing parturient is not at an increased risk for thrombocytopenia. The incidence of thrombocytopenia $\left(<140 \times 10^{9} \cdot \mathrm{L}^{-1}\right)$ was $2.5 \%$ in the cocaine-positive group and $4.7 \%$ in the cocaine-negative group. ${ }^{40}$
Myocardial infarction (MI) is a rare event during pregnancy with an estimated incidence of 1 in 10,000 pregnancies, ${ }^{41}$ although ECG changes suggestive of ischaemia occur in up to $37 \%$ of parturients undergoing elective caesarean section. ${ }^{42}$ The most common cause is atherosclerotic disease. Approximately 30\% have coronary artery examination by either angiography or postmortem examination. Other less common causes include anomalous origins of coronary arteries, inflammatory diseases, vasospastic phenomena, and spontaneous coronary artery dissection..$^{43}$ Peripartum MI has a high mortality rate of $30-40 \% .41$ The timing of the MI effects the mortality: third trimester infarction carries a $45 \%$ mortality rate compared with $23 \%$ in the first and second trimesters. ${ }^{43}$ In one study, 23 out of 75 fetuses died, and $65 \%$ of those deaths occurred at the same time as maternal death. ${ }^{44}$ In general, fetal outcome correlates with maternal outcome. The mode and timing of delivery after MI remain controversial. In a chronic instrumented model, Covert et al. ${ }^{45}$ found that in conscious ewes, cocaine caused maternal and fetal hypertension, reduced uterine artery blood flow, induced fetal hypoxaemia, and increased fetal cerebral vascular resistance. These cocaine-induced changes were attenuated or abolished in anaesthetized sheep. Due to haemodynamic instability, general anaesthesia with moderate-high dose opioid and invasive hemodynamic monitoring is often required. ${ }^{46}$

\section{Conclusion}

A careful history and physical examination with a high index of suspicion is essential to determine the differential diagnosis of substance abuse toxicity. Drug interaction is the most prominent cause of perioperative morbidity and mortality. Tetracaine or lidocaine should replace cocaine for topical anaesthesia. Halothane, which is more arrhythmogenic than isoflurane, should be avoided. Direct-acting sympathomimetics e.g., ketamine and vasoconstrictors that are substrates for neuronal amine re-uptake should also be avoided. Adequate depth of anaesthesia should be achieved if administered. Cocaine and its metabolites have deleterious effects on maternal and fetal haemodynamics and blood flow. Postoperative recovery and monitoring of these patients should also not be overlooked. Continuous electrocardiographic and arterial blood pressure monitoring is vital because fatal cocaine cardiotoxicity is unpredictable and rapid in onset.

\footnotetext{
References

1 McKenzic D, Williams B. Licit and Illicit Drugs, CCSA/ARF 1995 Canadian Profile. In: Addiction Research Foundation 1996; 118-204.
} 
2 Brookboff D, Campbell EA, Shaw LM. The underreporting of cocaine-related trauma: drug abuse warning network vs. hospital toxicology tests. Am J Public Health 1993; 83: 369-71.

3 Cheng DCH. Perioperative care of the patient abusing cocaine. Current Opinion in Anesthesiology 1996; 9: 259-62.

4 Cheng DCH. The perioperative care of cocaine-abusing patients. Can J Anaesth 1994; 41: 883-7.

5 McCalla S, Minkoff HL, Feldman J, Glass L, Valencia G. Predictors of cocaine use in pregnancy. Obstet Gynecol 1992; 79: 641-4.

6 Kliman L. Drug dependence and pregnancy: antenatal and intrapartum problems. Anaesth Intensive Care 1990; 18: 358-60.

7 Van Dyke C, Barash PG, Jatlow P, Byck R. Cocaine: plasma concentrations after intranasal application in man. Science 1976; 191: 859-61.

8 Inaba T, Stewart DJ, Kalow W. Metabolism of cocaine in man. Clin Pharmacol Ther 1978; 23: 547-52.

9 Baumann $M H$, Char GU, De Costa BR, Rice KC, Rothman RB. GBR12909 attenuates cocaine-induced activation of mesolimbic dopamine neurons in the rat. J Pharmacol Exp Ther 1994; 271: 1216-22.

10 Karoum F, Chrapusta SJ, Brinjak R, Hitri A, Wyatt $R J$. Regional effects of amphetamine, cocaine, nomifensine and GBR 12909 on the dynamics of dopamine release and metabolism in the rat brain. $\mathrm{Br} \mathrm{J}$ Pharmacol 1994; 113: 1391-9.

11 Miserendino MJD, Nestler EJ. Behavioral sensitization to cocaine: modulation by the cyclic AMP system in the nucleus accumbens. Brain Res 1995; 674: 299-306.

12 Lange RA, Cigarroa RG, Yancy CW Jr, et al. Cocaineinduced coronary-artery vasoconstriction. $\mathrm{N}$ Engl J Med 1989; 321: 1557-62.

13 Kissner DG, Lawrence WD, Selis JE, Flint A. Crack lung: pulmonary disease caused by cocaine abuse. Am Rev Respir Dis 1987; 136: 1250-2.

14 Hoffman CK, Goodman PC. Pulmonary edema in cocaine smokers. Radiology 1989; 172: 463-5.

15 Gawin FH, Ellinwood EH Jr. Cocaine and other stimulants. Actions, abuse and treatment. N Engl J Med 1988; 318: 1173-82.

16 Fleming JA, Byck R, Barash PG. Pharmacology and therapeutic applications of cocaine. Anesthesiology 1990; 73: 518-31.

17 Roth D, Alarcón FJ, Fernandez JA, Preston RA, Bourgoignie JJ. Acute rhabdomyolysis associated with cocaine intoxication. N Engl J Med 1988; 319: 673-7.

18 Sharff JA. Renal infarction associated with intravenous cocaine use. Ann Emerg Med 1984; 13: 1145-7.
19 Goodman PE, Rennie WP. Renal infarction secondary to nasal insufflation of cocaine. Am J Emerg Med 1995; 13: 421-3.

20 Teoh SK, Sarnyai $Z$, Mendelson $J H$, et al. Cocaine effects on pulsatile secretion of ACTH in men. J Pharmacol Exp Ther 1994; 270: 1134-8.

21 Bernards $C M$, Teijeiro A. Illicit cocaine ingestion during anesthesia. Anesthesiology 1996; 84: 218-20.

22 Berger $J L$, Nimier $M$, Desmonts $J M$. Continuous axillary plexus block in the treatment of accidental intraarterial injection of cocaine (Letter). N Engl J Med 1988; 318: 930.

23 Barash PG, Kopriva CJ, Langou $R$, et al. Is cocaine a sympathetic stimulant during general anesthesia? JAMA 1980; 243: 1437-9.

24 Boylan JF, Cheng DCH, Sandler $A N$, et al. Cocaine toxicity and isoflurane anesthesia: hemodynamics and myocardial metabolism. J Cardiothorac Vasc Anesth 1996; 10: 772-7.

25 Koebntop DE, Liao J-C, Van Bergen FH. Effects of pharmacologic alterarions of adrenergic mechanisms by cocaine, tropolone, aminophylline, and ketamine on epinephrine-induced arrhythmias during halothane-nitrous oxide anesthesia. Anesthesiology 1977; 46: 83-93.

26 Murphy $J L J r$. Hypertension and pulmonary oedema associated with ketamine administration in a patient with a history of substance abuse. Can J Anaesth 1993; 40: 160-4.

27 Kenny D, Pagel PS, Warltier DC. Attenuation of the systemic and coronary hemodynamic effects of cocaine in conscious dogs: propranolol versus labetalol. Basic Res Cardiol 1992; 87: 465-77.

28 Gay GR, Loper KA. The use of labetalol in the management of cocaine crisis. Ann Emerg Med 1988; 17: 282-3.

29 Pollan S, Tadjziechy $M$. Esmolol in the management of epinephrine- and cocaine-induced cardiovascular toxicity. Anesth Analg 1989; 69: 663-4.

30 Hale L, Alkes KJ, Rezkalla SH, Eisenhauer, Kloner RA. Nifedipine protects the heart from the acute deleterious effects of cocaine if administered before but not after cocaine. Circulation 1991; 83: 1437-47.

31 Mets $B$, Virag L. Lethal toxicity from equimolar infusions of cocaine and cocaine metabolites in conscious and anesthetized rats. Anesth Analg 1995; 81 : 1033-8.

32 Ashchi M, Wiedemann HP, James KB. Cardiac complication from use of cocaine and phenylephrine in nasal septoplasty. Arch Otolaryngol Head Neck Surg 1995; 121: $681-4$.

33 Singh PP, Dimich I, Shamsi A. Intraoperative pulmonary oedema in a young cocaine smoker. Can J Anaesth 1994; $41: 961-4$. 
34 El-Din ASMAK, Mostafa SM. Severe hypertension during anaesthesia for dacryocystorhinostomy. Anaesthesia 1985; 40: 787-9.

35 Antelman SM, Kocan D, Rowland N, de Giovanni L, Chiodo $L A$. Amitriptyline provides long-lasting immunization against sudden cardiac death from cocaine. Eur J Pharmacol 1981; 69: 119-20.

36 Tordoff SG, Stubbing JF, Linter SPK. Delayed excitatory reaction following interaction of cocaine and monoamine oxidase inhibitor (phenelzine). Br J Anaesth 1991; 66: 516-8.

37 Fekete $M$, Borsy J. Chlorpromazine-cocaine antagonism: its relation to changes of dopamine metabolism in the brain. Eur J Pharmacol 1971; 16: 171-5.

38 Little BB, Snell LM, Klein VR, Gilstrap LC III. Cocaine abuse during pregnancy: maternal and fetal implications. Obstet Gynecol 1989; 73: 157-60.

39 Levy $M$, Koven $G$. Obstetric and neonatal effects of drugs abuse. Emerg Med Clin North Am 1990; 8: 633-51.

40 Gershon RY, Fisher AJ, Graves WL. The cocaine-abusing parturient is not at an increased risk for thrombocytopenia. Anesth Analg 1996; 82: 865-6.

41 Hankins GDV, Wendel GD Jr, Leveno KJ, Stoneham J. Myocardial infarction during pregnancy: a review. Obstet Gynecol 1985; 65: 139-46.

42 Palmer CM, Norris $M C$, Giudici $M C$, Leighton $B L$, DeSimone $C A$. Incidence of electrocardiographic changes during cesarean delivery under regional anesthesia. Anesth Analg 1990; 70: 36-43.

43 Nolan TE, Hankins GDV. Myocardial infarction in pregnancy. Clin Obstet Gynecol 1989; 32: 68-75.

44 Aglio LS, Johnson MD. Anaesthetic management of myocardial infarction in a parturient. $\mathrm{Br} \mathrm{J}$ Anaesth 1990; 65: 258-61.

45 Covert RF, Schreiber MD, Tebbett IR, Torgerson LJ. Hemodynamic and cerebral blood flow effects of cocaine, cocaethylene and benzoylecgonine in conscious and anesthetized fetal lambs. J Pharmacol Exp Ther 1994; 270: 118-26.

46 Liu SS, Forrester RM, Murphy GS, Cheng $K$, Glassenberg $R$. Anaesthetic management of a parturient with myocardial infarction related to cocaine use. Can J Anaesth 1992; 39: 858-61. 
Davy C.H. Cheng MD MSC FRCPC

\section{Le patient toxicomane}

$\mathrm{L}$ E dossier de l'usage des drogues au Canada est loin d'être complet. On estime qu'un Canadien adulte sur cinq ou $4,200,000$ personnes ont consommé une drogue illégalement au moins une fois pendant leur vie. Vingt pour cent des canadiens adultes auront fait usage de cannabis (marijuana, haschisch) qui demeure la drogue la plus répandue. Trois pour cent ou 640,000 personnes avouent avoir consommé de la cocaïne, du crack ou du LSD. Deux pour cent ou 427,000 personnes ont consommé des amphétamines (speed) et moins de un pour cent ou 213,000 personnes de l'héroïne au moins une fois. Au cours des cinq dernières années, l'usage de toutes ces drogues par les canadiens a diminué, surtout le cannabis et la cocaïne. En général, l'usage de drogues illicites est plus élevé parmi les personnes à bas revenus, les sans emploi et dans des grands centres urbains. ${ }^{1}$ Une étude récente réalisée dans un grand centre de traumatologie américain révélait que l'urine ou le sang de $57 \%$ des victimes d'assauts et $22 \%$ des victimes d'accidents d'automobiles contenait de la cocaine ou un de ses métabolites. ${ }^{2}$

L'utilisation illicite des drogues pose toujours pour l'anesthésiste un des problèmes les plus difficiles à résoudre particulièrement pour la chirurgie d'urgence. On peut donner comme exemple le jeune intoxiqué à la cocaïne victime d'un accident d'automobile qui souffre d'une fracture ouverte d'un membre inférieur secondaire et qui présente de la tachyarythmie, de l'ischémie myocardique et de l'acidose métabolique; ou encore la parturiente de 30 semaines admise admise pour une césarienne en urgence à cause d'un travail prématuré avec une bradycardie foetale, une hémorragie par décollement prématuré du placenta, de l'hypertension et des arythmies cardiaques secondaires à l'utilisation récente de cocaïne. Chez le toxicomane, l'abus de plusieurs drogues est la règle plutôt que l'exception.

Cet exposé vise à attirer l'attention sur cet important problème et passer en revue la prise en charge anesthésique périopératoire de ces patients, particulièrement en ce qui concerne l'abus de la cocaïne. ${ }^{3,4}$

\section{Évaluation préopératoire}

Il faut d'abord se méfier car ces patients n'avouent pas volontiers leur toxicomanie. Ce diagnostic se précise en face d'une constriction de la pupille, de trainées cutanées, de tromboses veineuses, d'oedème cutané périveineux, d'abcès sous-cutanés ou de cicatrices, de tatouages, de lymphadénopathie, d'hépatomégalie, de comportement bizarre et d'une histoire de maladie associée à la toxicomanie. En cas de soupçon, un dépistage urinaire s'impose. Ils présentent la plupart du temps des symptômes d'origine cardio-pulmonaire, psychiatrique et neurologique. Le tableau I résume les signes et symptômes usuels de la toxicomanie.

Pendant la grossesse, un grand nombre de substances sont en cause et la toxicomanie se manifeste de plusieurs façons. La toxicomanie est généralement associée à un manque de soins prénataux. ${ }^{5}$ Jusqu'à $50 \%$ des parturientes toxicomanes souffrent d'au moins une complication médicale ou chirurgicale parmi les suivantes : l'anémie (généralement par déficience en acide folique), l'hépatite aiguë et chronique, les maladies transmises sexuellement, la septicémie, l'endocardite bactérienne, la thrombophlébite, la pneumonie, les infections urinaires, le sida, les maladies psychiatriques et la malnutrition grave, une complication obstétricale

TABLEAU I Signes et symptômes de la toxicomanie

\begin{tabular}{ll}
\hline Cannabis & - Tachycardie, labilité tensionnelle. \\
& - Euphorie. Anxiété et réaction de panique occasionnelles. \\
Cocaïne et & Médiocrité de la mémoire et de la motivation avec l'usage chronique. \\
amphétamine & - Tachycardie, labilité tensionnelle, hypertension. \\
& . Excitation, délire, hallucinations évoluant vers la psychose. \\
Hallucinogènes & - Hyperéflexie, tremblements, convulsions, mydriase, transpiration, hyperpyrexie, épuisement et coma avec la surdose. \\
LSD & - Sympathicomimétiques et faibles analygésiques. \\
& - Altération de la perception et du jugement. Effets toxiques à doses élvées. \\
Morphiniques & - Á doses corissantes, la phencyclidine produit une anesthésie dissociative. \\
& - Euphorie surtout avec l'héroïne. \\
& - Pupilles en trou d'épingle avec la surdose. Altération jusqu'au coma de la conscience.
\end{tabular}


majeures dont le retard de croissance intra-utérine, le travail prématuré, l'hypertension, la présentation du siège et l'hémorragie antépartum. ${ }^{6}$

\section{Cocaïne}

Ceux qui font l'abus de cocaïne à cause de ses effets stimulants le font souvent en «sniffant» sa fine poudre blanche souvent appelée «neige». Toutefois, au milieu des années 1980, une nouvelle forme peu coûteuse de cocaïne, le "crack" a fait son apparition. Le crack est une forme hautement concentrée de cocaïne reconstituée ayant l'apparence d'une pierre inhalée par l'utilisateur. En 1990 , le crack, un puissant toxicomanogène, est devenu la drogue illicite dont on abuse le plus fortement aux États-Unis.

La cocaïne $\left(1,5 \mathrm{mg} \cdot \mathrm{kg}^{-1}\right)$ est absorbée rapidement par la muqueuse nasale avec des concentrations plasmatiques de pointe $\left(120-474 \mathrm{ng} \cdot \mathrm{ml}^{-1}\right)$ après $30-60$ minutes et peut être détectée dans le plasma pendant au moins 6 heures. ${ }^{7}$ La cocaine a une demi-vie biologique de 0,5 à 1,5 heures, un volume de distribution de $2 \mathrm{~L} \cdot \mathrm{kg}^{-1}$ et une clairance systémique de $2 \mathrm{~L} \cdot \mathrm{min}^{-1}$. Seulement $1-5 \%$ de la cocaïne est éliminée sans métabolisme dans l'urine où elle peut être détectée de trois à six heures après son utilisaton. Cependant, ces deux métabolites principaux (80\%), le méthyl ester d'ecgonine et le benzylecgonine, persistent dans l'urine pendant 14-60 heures après l'administration de cocaïne. Pour son métabolisme, la cocaïne est hydrolysée par la cholinestérase plasmatique. ${ }^{8}$

La toxicité à la cocaïne se manifeste surtout par des symptômes cardio-pulmonaires (40\%), psychiatriques (22\%) et neurologiques (13\%). Il est important de se rappeler que ces patients abusent généralement de plusieurs drogues. La cocaïne produit une stimulation centrale et périphérique par:

l'inhibition de la recapture pré-synaptique de la dopamine, ${ }^{9}$

l'augmentation de la libération de dopamine, ${ }^{10}$

l'augmentation des niveaux de l'adénine cyclase et de la protéine kinase AMP cyclique dépendante (PKA). ${ }^{11}$

Manifestations cardio-pulmonaires: La cocaïnomanie aiguë peut se manifester par de la tachycardie, de l'hypertension grave, une dissection aortique aiguë, de l'arythmie cardiaque, de la fibrillation ventriculaire, de l'ischémie myocardique, par l'infarctus et la mort subite. ${ }^{4} \mathrm{La}$ cocaïne aggrave l'insuffisance coronaire, induit le spasme coronaire et diminue le débit sanguin coronaire. ${ }^{12}$ En inhalation, la cocaïne provoque l'hémorragie alvéolaire et l'oedème pulmonaire aigu. ${ }^{13,14}$

Manifestations psychiatriques: La cocaine provoque de l'excitation, de l'exubérance, une sensation de bien- être, de capacité mentale et de force physique augmentée et d'une diminution de la perception de la fatigue. L'utilisateur chronique peut développer une psychose paranoïde toxique totale qui peut aller jusqu' à un comportement antisocial violent. L'usage à long terme peut aussi causer une perte de poids, une détérioration du système nerveux et des problèmes digestifs. La cocaïne crée l'accoutumance psychologique. Le retrait subit s'accompagne de faim, de fatigue et de dépression. ${ }^{15}$

Manifeatations neurologique: Ces patients peuvent présenter un vasospasme cérébral, de l'ischémie ou un ictus, de l'hyperpyrexie et de la rigidité musculaire. ${ }^{19}$ Pendant l'anesthésie générale, l'hyperpyrexie peut atteindre $41^{\circ} \mathrm{C}$ et l'activation sympathicominétique par surdosage peut simuler une crise d'hyperthermie maligne. ${ }^{16}$

Manifestations rénales: La défaillance rénale myoglobinurique secondaire à la rhabdomyolise constitue la complication rénale la plus souvent rapportée. ${ }^{17}$ On a aussi rapporté des infarctus rénaux secondaires à l'abus de cocaïne intra-veineuse, ${ }^{18}$ et au «sniffing». ${ }^{19}$

Manifestations endocriniennes: Après l'intoxication aiguë à la cocaïne, la sécrétion de l'hormone adrénocorticotrope (ACTH) augmente considérablement. Comme la fréquence le pouls de l'ACTH n'est pas altérée par la cocaïne, on a postulé que la cocainne stimulait la mise en circulation du facteur de libération de la corticotropine et que la sécrétion de ce facteur induite par la cocaïne augmentait l'amplitude des pulsations de l'ACTH. ${ }^{20}$ Chez les cocaïnomanes, la relation entre l'augmentation de la sécrétion de l'ACTH et l'association de complications comme l'hypertension et les dérèglements psychiatriques nécessite une investigation plus poussée.

\section{Gestion peropératoire et interactions médicamenteuses}

À cause de la létalité causée par les arythmies cardiaques, l'oedème pulmonaire, le spasme coronarien, l'ischémie myocardique et la mort subite, il est possible que le cocaïnomane ne parvienne jamais à nos salles d'opération. Ce sont les cas de toxicité quasimortels où interviennent les interactions médicamenteuses comme principale cause de morbidité et de mortalité périopératoires qui nous concernent. En face d'une réaction défavorable, les manoeuvres immédiates devraient être dirigées vers la protection des voies aériennes, le maintien d'une ventilation suffisante, le contrôle du rythme et de l'hémodynamique, le traitement des convulsions et la régulation de la température. $^{3}$ 
L'observation suivante fournit une opportunité unique d'observer la physiologie et la pharmacologie pendant une intoxication aiguë à la cocaïne. ${ }^{21}$ Une jeune femme subissait une fracture ouverte de l'astragale au cours d'un accident d'automobile. De crainte de les perdre ou de se les faire voler, elle avait placé six «roches» de crack dans son nez et sous sa langue à l'appel de la salle d'opération. Sous le plan neurologique, elle a eu besoin d'une dose plus forte de benzodiazépine pour neutraliser la stimulation du système nerveux central et l'agitation provoquées par la cocaïne. L'intoxication aiguë a diminué la puissance efficace du midazolam parce que les benzodiazépine agissent en augmentant l'activité inhibitrice GABA dans le SNC. L'instabilité hémodynamique a suivi l'agitation et l'induction subséquente de l'anesthésie générale.

\section{Anesthésie locale ou régionale}

Pour le personnel médical, l'utilisation d'aiguilles augmente le risque des dangers de transmission par piqûre. Avant de procéder avec la locorégionale, il faut élimimer le sepsis, les désordres de la coagulation par dysfonctionnement hépatique et les neuropathies périphériques pré-existantes causées par la toxicomanie. À part ces complications, il n'existe pas de contre-indication absolue à l'anesthésie régionale. L'ajout d'adrénaline aux anesthésiques locaux peut induire de la tachycardie. Pour traiter un cas d'ischémie du membre supérieur causé par une injection intra-artérielle inadvertante de cocaïne, un bloc plexique axillaire a été réalisé avec $40 \mathrm{ml}$ de lidocaïne à $1 \%$ et maintenu pendant 36 heures avec une perfusion continue de bupivacaïne à $0,5 \%$ par un cathéter laissé au contact du plexus brachial. Le patient a reçu une perfusion continue d'héparine pendant 48 heures, remplacée par l'administration d'aspirine et de dipyridamol pendant 6 jours. L'évolution clinique a été favorable. ${ }^{22}$ Plusieurs autres stratégies pour le traitement des séquelles causées par des injections intra-artérielles ont été proposées dont le bloc du ganglion stellaire, l'administration de vasodilatateur intra-artériel, les vasodilatateurs systémiques, le dextran de bas poids moléculaire, ou la fasciectomie précoce.

\section{Anesthésie générale}

Des comptes rendus anecdotiques ont fait état de la toxicité systémique subite de la cocaïne avec l'anesthésie générale. Cette toxicité a une relation de cause à effet rarement simple, et implique ordinairement une interaction d'un produit vasoactif puissant avec la cocaïne. $\mathrm{La}$ cocaïne potentialise considérablement à la fois les sympathicomimétiques à action directe et les autres substrats vasoactifs pour la recapture neuronale aminée.
L'adminsitration topique de $1,5 \mathrm{mg} \cdot \mathrm{kg}^{-1}$ de cocaïne ou une concentration plasmatique équivalente de 330 $\mathrm{ng} \cdot \mathrm{ml}^{-1} \mathrm{n}^{\prime}$ a pas d'effets sympathicomimétiques cliniquement importants pendant l'anesthésie du coronarien. ${ }^{23}$ La stimulation sympathique irrésistible causée par une surdose de cocaïne peut être abolie par un plan d'anesthésie général profond. ${ }^{24}$ Il semble que l'influence des stimuli qui augmentent les concentrations endogènes d'épinéphrine et de norépinéphrine est plus susceptible aux complications causées par la cocaine. Pour cette raison, l'interaction des médicaments vasoactifs avec la cocaïne doit être sous haute surveillance pendant l'anesthésie générale.

L'halothane peut diminuer le seuil arythmogéne de l'épinéphrine. La kétamine potentialise aussi de beaucoup la toxicité cardiovasculaire de la cocaïne. ${ }^{25}$ L'association de crack et de kétamine peut prédisposer à l'hypertension artérielle pulmonaire et à l'oedème pulmonaire. ${ }^{26}$ Une redistribution transmurale du débit sanguin cardiaque indépendante de la profondeur de l'anesthésie a été observée pendant l'administration de cocaïne; elle pourrait résulter d'une interaction entre les augmentations de la perfusion myocardique globale dépendante de la demande et la vasoconstriction épicardique coronaire induite par la cocaïne. Pendant l'anesthésie à l'isoflurane et à des doses toxiques de cocaïne, le débit sanguin aux autres organes importants est préservé à l'exception du débit splénique qui est réduit. ${ }^{24} \mathrm{La}$ toxicité cardio-vasculaire et neurologique de la cocaïne peut être en rapport avec sa haute affinité et son accumulation dans les organes riches en vaisseaux sanguins. Une profondeur d'anesthésie suffisante est done nécessaire pour contrôler les effets cardiovasculaires de la cocaïne.

\section{Médicaments cardiopasculaires}

Le bloc alpha et bêta adrénergique diminue les effets hémodynamiques de la cocaïne plus que le bloc bêta seul. ${ }^{27}$ Le propanolol est donc relativement contreindiqué chez le cocaünomane étant donné que le blocage bêta est susceptible de provoquer sans opposition une stimulation alpha adrénergique et, donc, d'aggraver l'hypertension. Avec un blocage alpha et bêta, le labétalol permet un meilleur contrôle de l'hypertension. ${ }^{28}$ L'esmolol a permis de contrôler l'hypertension sans vasoconstriction coronaire et périphérique à médiation alpha. ${ }^{29}$ Des études expérimentales suggèrent que les inhibiteurs calciques peuvent être utiles dans le traitement la cardiotoxicité de la cocaïne. ${ }^{30}$ Sur le plan pharmacologique, l'action bloquante des canaux sodiques par la cocaïne en soi ne conduit pas à la mort par arythmie. D'autres facteurs, comme le tonus sympathique, potentialisent les effets arythmogènes de la cocaïne. Un 
puissant sympathicomimétique indirect, la cocaïne à dose toxique peut provoquer du dysfonctionnement ventriculaire gauche et de l'ischémie (par vasospasme ou accélération de la maladie coronaire). Quand une combinaison de ces facteurs se joint à un blocage important du sodium, la mort subite survient par arythmie ventriculaire. La cocaine et ses métabolites dépriment la fréquence du noeud sinusal. Pour la prise en charge de l'intoxication à la cocaïne, les médicaments qui inhibent la cholinestérase plasmatique devraient donc sans doute être évités. ${ }^{31}$

TABLE II Traitement de l'intoxication à la cocaïne

\begin{tabular}{ll}
\hline Sympt6mes & Traitement \\
\hline Hypertension/Tachycardic & Labétalol, csmolol \\
Arhythmias & Lidocaïne \\
Ischémie myocardique & Nitroglycérin \\
Tremblements/convulsions & Benzodiazépines \\
\hline
\end{tabular}

\section{Les pasoconstricteurs}

La littérature chirurgicale et anesthésique abonde sur les effets défavorables de la cocaïne en association avec les vasoconstricteurs. Au cours de l'intoxication aiguë à la cocaïne, les vasoconstricteurs comme l'hydrochlorure de phényléphrine (néo-synéphrine) ${ }^{32,33}$ et la félypressin ${ }^{34}$ peuvent précipiter des crises hypertensives, de la tachycardie ventriculaire, de l'ischémie myocardique, et un infarctus du myocarde.

\section{Les médicaments psychoactifs}

L'interaction avec les médicaments psychotropes est imprévisible. On a montré que les antidépresseurs tricycliques comme l'amitriptyline bloquent la recapture de la monoamine, ont un effet protecteur sur la mortalité seulement quand ils sont administrés soit dix jours ou un jour à des animaux de laboratoire avant une dose létale de cocaïne. ${ }^{35}$ La phénelzine (un inhibiteur de la monoamine oxydase) aurait provoqué une réaction retardée d'excitation qui s'est manifestée par des convulsions et de l'hyperpyrexie. ${ }^{36}$ Les benzodiazépines, qui ont un effet sur le système limbique, semblent le meilleur traitement contre les convulsions induites par la cocaïne. La chlorpromazine a été utilisée pour traiter l'hyperthermie mais elle peut abaisser le seuil des convulsions. ${ }^{37}$

\section{Gestion postopératoire}

L'ÉCG et le monitorage de la pression artérielle postopératoires sont essentiels. L'installation d'un monitorage cardiovasculaire invasif dépend de l'évolution périopératoire. Les syndromes de retrait des stimulants comme la cocaïne et l'amphétamine peuvent être difficiles à reconnaître. Vingt-quatre à quarante-huit heures après l'arrêt d'une période d'abus chronique, certains toxicomanes entrent dans une phase de sommeil ( «crash») prolongée heures suivie par de la faim, de la dépression, du délire et d'hallucinations. Ce syndrome serait causé par une déplétion de catécholamine, ${ }^{47}$ un mécanisme contraire à celui l'intoxication aiguë. Le syndrome doit suivre son évolution mais une dépression grave peut nécessiter l'aide du psychiatre.

\section{Évolution et complications anténatales}

À la période périnatale, l'abus de cocaïne est associé à de nombreuses complications materno-foetales dont une incidence accrue de décollements prématurés, de travail précoce, de distresse foetale nécessitant une césarienne, d'enfants de petit poids et de malformations congénitales. ${ }^{38}$ La cocaïnomanie est aussi associée à des anomalies du tractus génito-urinaire et à de la vasoconstriction entraînant une détérioration de la fonction placentaire ou un décollement placentaire ${ }^{39}$ évoluant vers l'atrésie intestinale, la perte de doigts et l'infarctus cérébral in utero. La cocaïnomane parturiente ne constitue pas un risque accru de trombocytopénic. L'incidence de la trombocytopénie $\left(<140 \times 10^{9} .1\right)$ était de $2,5 \%$ dans le groupe cocaüne- positif vs $4,7 \%$ dans le groupe cocaünenégatif. ${ }^{40}$

L'infarctus myocardique est un événement rare pendant la grossesse avec une incidence estimée de $1 / 10000$ grossesses, ${ }^{41}$ bien qu'on ait observé des changements ECG suggestifs d'ischémie chez $37 \%$ des parturientes soumises à une césarienne élective. ${ }^{42}$ L'étiologie la plus commune est la maladie coronaire athérosclérotique révélée dans environ $30 \%$ des cas par l'examen du système artériel coronaire angiographique ou post mortem. Les autres causes moins fréquentes sont les anomalies d'insertion des artères coronaires, les maladies inflammatoires, la vasospacité et la dissection spontanée de l'artère coronaire. ${ }^{43}$ Le taux de mortalité de l'infarctus du myocarde péripartum s'élève à $30-40 \%{ }^{41}$ La chronologie de l'infarctus influence la mortalité: l'infarctus du troisième trimestre a un taux de mortalité de $45 \%$ dont $23 \%$ dans les premier et second trimestre. ${ }^{43}$ Une étude mentionne que 23 des 75 foetus sont morts et $65 \%$ des mortalités foetales survenaient en même temps que la mortalité maternelle. ${ }^{44}$ En général, le pronostic foetal est parallèle à celui de la mère. Après un infarctus, le mode et le moment de l'accouchement demeurent controversés. Sur un modèle expérimental, Covert et $a l .^{45}$ ont trouvé que chez des brebis conscientes, la cocaüne provoquait de l'hypertension maternelle et foetale, une réduction du débit sanguin coronaire, de l'hypoxémie foetale et une augmentation de la résistance cérébrale vasculaire foetale. Sur le même 
modèl, l'anesthésie générale diminue ou abolit ces changements induits par la cocaïne. L'instabilité hémodynamique commande souvent une anesthésie générale avec des doses modérées à fortes de morphinique et un monitorage hémodynamique invasif. ${ }^{46}$

\section{Conclusion}

L'histoire détaillée et un examen physique avec un indice élevé de suspicion est essentiel pour déterminer le diagnostic différentiel de la toxicomanie. L'interaction médicamenteuse est la cause la plus importante de morbidité et de mortalité périopératoires. La tétracaïne et la lidocaine peuvent remplacer la cocaïne pour l'anesthésie de surface. L'halotane, qui est plus arythmogène que l'isoflurane, devrait être évité. Les sympaticomimétiques à action directe comme la kétamine et les vasoconstricteurs qui sont des substrats de la recapture neuronale aminée devraient aussi être évités. L'anesthésie générale devrait être assez profonde. La cocaïne et ses métabolites ont des effets délétères sur l'hémodynamique et le débit sanguin maternel et foetal. Chez ces patients, il faut porter une attention particulière à la récupération postopératoire et au monitorage. Le monitorage continu électrocardiographique et de la pression artérielle est vital parce que la létalité de la cardiotoxicité à la cocaïne est imprévisible et se manifeste sans avertissement.

\section{Références}

(Voir page Rl04) 